\title{
Expansion of seagrass habitat by the exotic Zostera japonica, and its use by dabbling ducks and brant in Boundary Bay, British Columbia
}

\author{
John R. Baldwin, James R. Lovvorn \\ Department of Zoology and Physiology, University of Wyoming, Laramie, Wyoming 82071, USA
}

\begin{abstract}
The exotic seagrass Zostera japonica was first documented on the Pacific Coast of North America in the late 1950s, and has extensively colonized formerly unvegetated tidal flats and dramatically altered the habitat structure. In Boundary Bay, British Columbia, Canada, there was an almost 17 fold increase in $Z$. japonica coverage between 1970 and 1991. In Boundary Bay's 6385 ha of intertidal and shallow subtidal area (tidal range $4.7 \mathrm{~m}$ ), $Z$. japonica occurred mostly from 0 to $-1.8 \mathrm{~m}$ Mean Water Level (MWL) and covered 3845 ha in October 1991 The native $Z$. marina occurred mostly from -0.9 to $-5.5 \mathrm{~m} \mathrm{MWL}$, and covered 3444 ha including 1684 ha of overlap with $Z$. japonica. Standing stock of $Z$. japonica, mostly in formerly unvegetated areas, measured 520 metric tonnes (t) above ground and 235 t below ground in October 1991 This introduced species provides an important feeding habitat for many migratory waterfowl. Percent dry mass of $Z$. japonica in esophagus contents of birds collected in Boundary Bay was $57.2 \%(n=62)$ in brant Branta bernicla, $84.8 \%(n=45)$ in American wigeon Anas americana, $72.3 \%(\mathrm{n}=20)$ in mallard $A$. platyrhynchos, $48.3 \%(\mathrm{n}=54)$ in northern pintail $A$. acuta, and $1.7 \%(\mathrm{n}=14)$ in green-winged teal $A$. crecca. Percent dry mass of the native $Z$. marina was $41.2 \%$ in esophagi of brant but only 0.1 to $4.6 \%$ in the other species. Grazing by brant and dabbling ducks, with peak numbers of about 80000 in early December, removed $50 \%$ (262 t) of the above-ground biomass and $43 \%(100 \mathrm{t})$ of the below-ground biomass of $Z$. japonica. This exotic seagrass thereby supported almost 4.6 million use days by these birds.
\end{abstract}

KEY WORDS: Zostera japonica - Zostera marina - Exotic · Grazing · Seagrass - Waterfowl

\section{INTRODUCTION}

Biological invasions have significantly changed many aquatic ecosystems, often adversely, e.g. spread of the submerged plant Myriophyllum spicatum in Chesapeake Bay, USA (Bayley et al. 1978), zebra mussels Dreissena polymorpha in the Gireat Lakes (Hebert et al. 1991), and the emergent grass Spartina alterniflora in San Francisco Bay, California, USA (Callaway \& Josselyn 1992). Effects of many other introductions are difficult to characterize. For example, about 100 exotic invertebrates have become established in San Francisco Bay, but their presence was not realized for nearly 100 years (Nichols \& Pamatmat 1988).

Zostera japonica was probably introduced to the north Pacific Coast of North America in the first half of this century along with oyster shipments from Japan. It was first documented in 1957 in Willapa Bay, Washington, USA, and in Boundary Bay, British Columbia, Canada, in 1969 (Fig. 1) (Harrison \& Bigley 1982). Since then $Z$. japonica has spread throughout Boundary Bay, northern Puget Sound, and the southern Strait of Georgia, as well as to coastal bays in Oregon, USA.

Zostera japonica has many characteristics of a successful invader. It has small body size (leaves usually $<20 \mathrm{~cm}$ long and $2 \mathrm{~mm}$ wide) and devotes up to $25 \%$ of its dry mass per unit area to flowering and seed production (Den Hartog 1970, Harrison 1979). Z. japonica's main reproductive strategy is to germinate in spring in mid to low intertidal zones that have been denuded by weather and storm waves in winter, and to produce many seeds before storms again uproot its shallow below-ground system in late autumn (Harrison 1982a). In contrast, the native $Z$. marina has a larger 
body size, with leaves often 50 to $120 \mathrm{~cm}$ long and 3 to $12 \mathrm{~mm}$ wide. In this north Pacific region, $Z$ marina devotes a large fraction of its resources to rhizomes and shoots for over-wintering and vegetative reproduction, and flowers comparatively little beginning only in its second year (Harrison 1979). (See Jacobs 1982 for contrasting strategies in Europe.) Z. marina overwinters at low intertidal to subtidal elevations, where exposure to storm waves and weather are reduced. Penetration to higher elevations by $Z$. marina appears limited by its lower resistance to desiccation, whereas at lower elevations the greater leaf growth of $Z$. marina, when continuously submerged under summer irradiance, may shade out $Z$. japonica (Harrison 1982b). Although some competition occurs between the 2 species, $Z$. japonica probably will not displace $Z$. marina (Harrison 1982b, Nomme 1989). Many bays in this north Pacific region were easily invaded by $Z$. japonica, because of an unoccupied niche and a physical and climatic similarity to the species' original habitat (Den Hartog 1970, Mukai et al. 1980).

Grazing of seagrasses and submerged aquatic vegetation (SAV) by waterfowl has been well documented (Cottam et al. 1944, Campbell 1946, Yocom \& Keller 1961, Ogilvie \& Matthews 1969, Grandy 1972, Charman 1977, 1979, Tubbs \& Tubbs 1983, Phillips 1984, Thayer et al. 1984, Mayhew 1988), and some workers have estimated the biomass removed (Ranwell \& Downing 1959, McRoy 1966, Stieglitz 1966, Anderson \& Low 1976, Cornelius 1977, Nienhuis \& Van Ierland 1978, Kiorboe 1980, Verhoeven 1980, Jacobs et al. 1981, Wilkins 1982, Ward 1983, Nienhuis \& Groenendijk 1986, Mitchell 1991). However, there is almost no published information on waterfowl use of Zostera japonica. Thom et al. (1991) estimated the mass of carbon of $Z$. marina and $Z$. japonica removed by brant Branta bernicla, American wigeon Anas americana, mallard A. platyrhynchos, northern pintail A. acuta and green-winged teal A. crecca in Padilla Bay, Washington (Fig. 1); however, they lacked data on the fraction of either Zostera species in bird diets.

In this study we document the dramatic spread of Zostera japonica in Boundary Bay, its contribution to waterfowl diets, and its biomass grazed by waterfowl.

\section{MATERIALS AND METHODS}

Study area. Boundary Bay, SW British Columbia, Canada, is delimited partly by the USA-Canada border (Fig. 1). Boundary Bay is in the Fraser River Delta, but fresher water from the Fraser River probably never enters the Bay. Boundary Bay is freshened slightly on the east end by 2 small rivers, but salinity throughout most of the Bay remains near levels in the Strait of

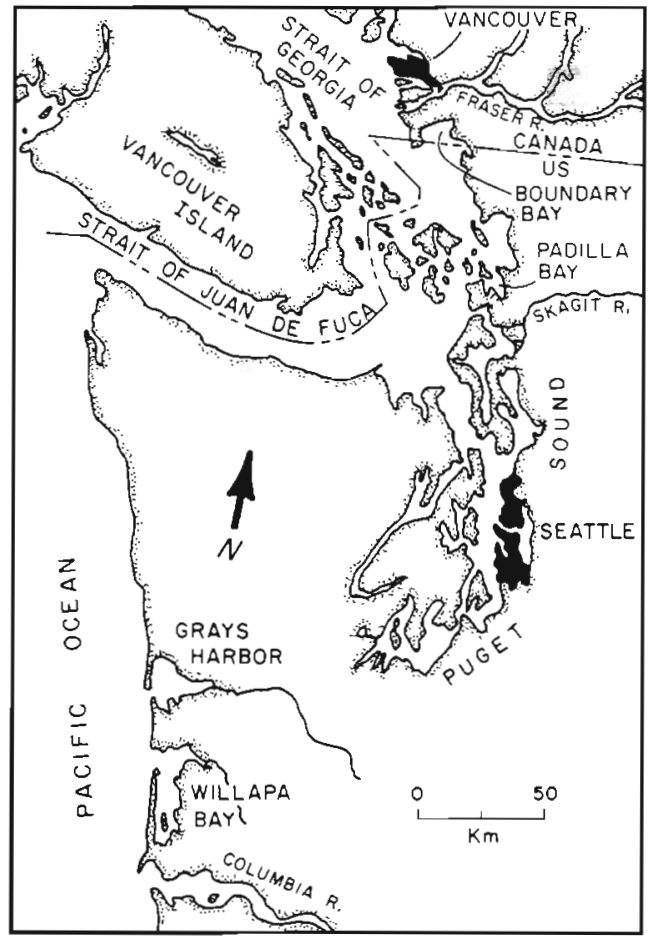

Fig. 1. Southwest British Columbia, Canada, and western Washington, USA

Georgia (24 to $29 \%$ ) (Waldichuk 1957). A mixed semidiurnal tide (2 high and 2 low tides each lunar day) over a $4.7 \mathrm{~m}$ elevational range results in extensive tidal flats. Tide references in this paper are to Mean Water Level $(\mathrm{MWL}=$ Geodetic Datum) and Lower Low Water (LLW = Chart Datum); see Forrester (1983) for explanation of tide terminology.

Zostera distribution and standing stock. Three $200 \mathrm{~m}$ transects were established in a monotypic stand of Zostera japonica in 1990-91 and 1991-92 in western Boundary Bay. Transects were 50 to $75 \mathrm{~m}$ apart, each with 20 stations at $10 \mathrm{~m}$ intervals marked with stakes. Percent cover within a $0.1 \mathrm{~m}^{2}(20 \times 50 \mathrm{~cm})$ rectangular frame was visually estimated at each station in October 1990 and September 1991 before most ducks arrived, and again in January 1991 and December 1991 after ducks had reached peak numbers.

Core samples were taken along 2 additional transects in early October, December and February in both years. Transects extended perpendicular to the shoreline from the edge of the salt marsh at 72 nd Street (Transect 1) and 96th Street (Transect 2) (see Fig. 3). Sampling stations were marked with stakes at $100 \mathrm{~m}$ intervals. Three cores per station were taken during each sampling period with a hand-held, galvanizedsteel sampler $(20 \mathrm{~cm}$ diameter) to a depth of 5 to $6 \mathrm{~cm}$. Samples were washed over a $0.5 \mathrm{~mm}$ screen and both 
leaves and rhizomes were sorted to species. Samples were oven-dried at $50^{\circ} \mathrm{C}$ and weighed.

Transect stations were surveyed for elevation using a stadia rod and level. Bench marks used as reference are relative to MWL or mean exposure time. Distributions of Zostera spp. relative to elevations along these transects were extrapolated to the entire Bay based on the bathymetric map of Kellerhals \& Murray (1969). The lower elevational limit of $Z$. marina was about $-5.5 \mathrm{~m}$ MWL (S. D. Freeman pers. comm.). Areal coverages of salt marsh, unvegetated sandflat, $Z$. japonica, mixed Zostera spp., and $Z$. marina were determined from maps (based on aerial photographs) with a Lasico electronic compensating polar planimeter. Aboveground and below-ground biomass were estimated from core samples taken along both transects in October 1991. Triplicate samples were pooled within stations and then averaged to estimate dry mass $\mathrm{m}^{-2}$. Mean biomass and areal coverage were used to calculate the biomass of $Z$. japonica leaves and rhizomes for the entire Bay. Areal coverage of Zostera spp. in 1970 was mapped from aerial photographs and verified by site inspection (British Columbia Dept of Wildlife, Burnaby, unpubl. data).

Waterfowl numbers. Numbers of American wigeon, northern pintail, mallard and green-winged teal were estimated every 7 to $10 \mathrm{~d}$ from September through March 1990-91 and 1991-92. Duck numbers were estimated with a spotting scope from points on the dike along the northern edge of the bay. Daylight, tide height, wind and fog dictated when estimates were possible. Daily 'waterfowl use days' (WUD) were calculated from averages of consecutive counts and summed for each species. No data for brant numbers were available, so use days were estimated by assuming that 500 brant were present for $20 \mathrm{~d}$. Total use days were used to calculate the biomass of Zostera japonica eaten by waterfowl from September to March (see below).

Foraging behavior. Foraging behavior of wigeon, pintails and mallards was observed from 1 October through 7 December 1990. Daylight hours were divided into 4 equal parts, and ducks were observed for 2 non-consecutive $30 \mathrm{~min}$ periods, once a week, during each of the 4 daylight periods. Tide heights during observations ranged from $\mathrm{ca}-1.1$ to $+2.1 \mathrm{~m} \mathrm{MWL}$. A focal bird (Altmann 1974) was randomly selected and observed for $20 \mathrm{~s}$ ( $\mathrm{n}=1153$ focal individuals). Duck behavior was recorded on cassette tapes, later transcribed, and the percent time spent feeding determined for 6 tide height ranges. These data were not normally distributed, so medians and 15 to $85 \%$ quantiles were used to delimit about the same fraction of the distribution as \pm 1 standard deviation $(68 \%)$.

Esophagus contents. Wigeon, pintail, mallard and green-winged teal were collected in Boundary Bay from October through January 1990-91 and 1991-92. Birds were collected during the day with a shotgun at most tidal ranges, although the lowest tides occur at night during winter in this area. Brant esophagi were obtained from hunters along the southwest shoreline of the Bay from 1 to 10 March 1992.

Esophagus contents were either immediately preserved in ethyl alcohol or frozen. Food items were sorted to species, oven-dried at $50^{\circ} \mathrm{C}$, and weighed to the nearest mg. Percent dry mass of each food item was calculated for each esophagus sample, and aggregate percentages (Swanson et al. 1974 ) were calculated for the major food groups of each species.

Eelgrass energy content. Samples of Zostera spp. were collected once a month from September to March. Leaves were washed to remove epiphytes, and all samples were freeze-dried to constant weight and ground to pass a $0.1 \mathrm{~mm}$ screen. A Phillipson microbomb calorimeter was used to estimate the gross energy in Zostera spp. leaves and rhizomes, and the seeds of $Z$. japonica. These estimates were used in calculating the biomass consumed by waterfowl (see below).

Biomass of eelgrass removed. Consumption of Zostera japonica leaves, rhizomes and seeds was estimated for wigeon, pintail, mallard and brant for both years. Biomass removed $(B R)$ by wigeon, pintail, mallard and brant was calculated by the following formula applied to each species:

$$
B R=\left[(D M \times D E E) /\left(\mathrm{kJ} \mathrm{g}^{-1}{ }_{\mathrm{l}, \mathrm{r}, \mathrm{s}} \times A M E\right)\right] \times W U D .
$$

$D M$ is the average fraction of esophagus contents (dry mass) made up of $Z$. japonica for a given species. Estimates of daily energy expenditure (DEE) were $631 \mathrm{~kJ}$ $\mathrm{d}^{-1}$ for wigeon (Mayhew 1988), $683 \mathrm{~kJ} \mathrm{~d}^{-1}$ for mallard (Morton et al. 1989), $660 \mathrm{~kJ} \mathrm{~d}^{-1}$ for pintail (interpolated for a body mass of $900 \mathrm{~g}$ from values for wigeon and mallard) and $842 \mathrm{~kJ} \mathrm{~d}^{-1}$ for brant (Drent et al. 1978/79). We measured gross energies of $Z$. japonica leaves, rhizomes and seeds ( $\left.\mathrm{kJ} \mathrm{g}^{-1}{ }_{1, \mathrm{r}, \mathrm{s}}\right)$ with micro-bomb calorimetry. We used literature values for apparent metabolizable energy ( $A M E$ ) of leaves (46\%; Buchsbaum et al. 1986), rhizomes (56\%; McRoy 1970, Karasov 1990) and seeds (59\%; Karasov 1990). Waterfowl use days were estimated as described above.

\section{RESULTS}

\section{Zostera distribution and standing stock}

Percent cover of Zostera japonica decreased from early fall to midwinter by an average of $88 \%$ the first year and $91 \%$ the second year (Table 1). In the first 
Table 1. Zostera japonica. Mean (SD) percent cover of eelgrass in Boundary Bay, British Columbia, during early fall and midwinter October 1990 vs January 1991 ( $\mathrm{n}=60$ stations), and September vs December 1991 ( $n=40$ stations)

\begin{tabular}{|c|c|c|c|c|}
\hline \multirow{2}{*}{ Year } & \multirow{2}{*}{ Transect } & \multicolumn{2}{|c|}{$\%$ Cover } & \multirow{2}{*}{$\%$ Loss } \\
\hline & & Early fall & Midwinter & \\
\hline \multirow[t]{3}{*}{$1990-91$} & 1 & $17.3(13.7)$ & $2.2(1.1)$ & $87.3(11.9)$ \\
\hline & 2 & $10.7(10.6)$ & $1.2(1.4)$ & $89.2(8.2)$ \\
\hline & 3 & $6.0(4.0)$ & $0.7(0.4)$ & $88.2(10.7)$ \\
\hline \multirow[t]{2}{*}{1991} & 1 & $56.4(23.5)$ & $4.1(2.7)$ & $92.5(4.0)$ \\
\hline & 2 & $64.0(21.8)$ & $6.0(4.1)$ & $90.4(6.4)$ \\
\hline
\end{tabular}

year, ice cover in mid-December (see Fig. 4) delayed the midwinter sample until January. In the second year, markers along one transect disappeared after the first sampling period, which prevented resampling.

Transect 1 was steeper and dropped sharply to below LLW, about $-2.6 \mathrm{~m} \mathrm{MWL}$, at $2.2 \mathrm{~km}$ from the edge of the salt marsh (Fig. 2). Transect 2 did not drop below LLW until about $4 \mathrm{~km}$ from the edge of the saltmarsh, but was not sampled beyond $2.6 \mathrm{~km}$ because of poor drainage and insufficiently low tides during winter sampling periods. Zostera japonica occurred in shallow pools above MWL, but its distribution generally began near MWL and extended to around $-1.8 \mathrm{~m}$ MWL. Z . marina occurred mostly below -0.9 m MWL. These elevational ranges are somewhat lower than reported for other sites in the region (e.g. Posey 1988, Thom 1990), probably because Boundary Bay has sandy sediments that drain faster and more completely, a steady elevational gradient (no persistent tide pools) and greater exposure to waves.

In 1970, about 211 ha of Zostera japonica were established in Boundary Bay (Fig. 3A). By 1991, coverage of $Z$. japonica had increased over 17 -fold to 3845 ha (Fig. 3B). Z. marina coverage increased $121 \%$ from 1560 ha in July 1970 to 3444 ha in October 1991. In October 1991, total eelgrass coverage was 5605 ha, with 1684 ha of overlap of the 2 Zostera species (Table 2). Based on the average biomass $\mathrm{m}^{-2}$ from pooled transect samples, the above-ground standing stock for 3845 ha of $Z$. japonica in October 1991 was 520 t $(95 \% \mathrm{CI}=399$ to 641$)$ and the belowground biomass (rhizomes) was 235 t $(95 \%$ C.I $=182$ to 288 ).
Tronsect 1

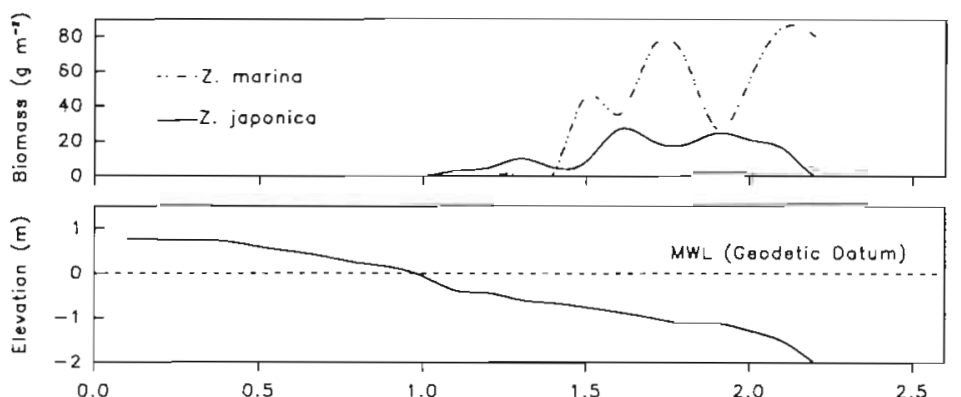

Tronsect 2

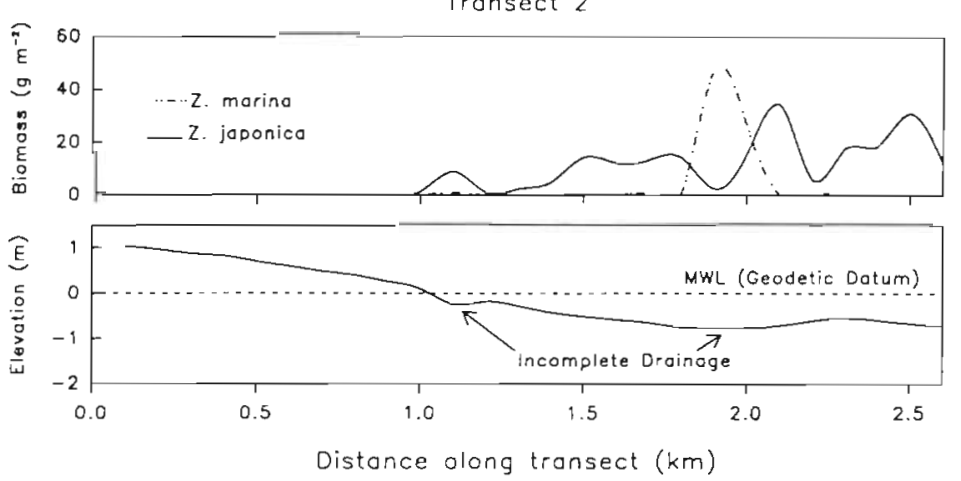

Fig. 2. Zostera marina, Z. japonica. Biomass of eelgrass in Boundary Bay, British Columbia, relative to Mean Water Level (MWL) and to distance along transects extending from the edge of the salt marsh perpendicular to the shoreline

\section{Duck numbers}

Duck numbers climbed steadily in Boundary Bay from September through November in both years (Fig. 4). Numbers peaked at about 80000 in early December and then declined, probably depending on weather conditions and food availability. In some winters such as 1990-91, extensive freeze-ups encourage ducks to continue migration or disperse from the area (authors' unpubl. data).

\section{Foraging behavior and diet}

Below MWL, wigeon, pintails and mallards spent most of their time feeding, whereas almost no time was spent feeding above MWL (Table 3). This abrupt elevational change in feeding effort corresponded to the upper limit of Zostera japonica (Fig. 2).

Zostera japonica comprised the largest percentage of the diet for all species except green-winged teal (Table 4). Leaves of $Z$. japonica were the single largest fraction of the diet for brant and wigeon, whereas the rhizomes of $Z$. japonica were the largest fraction for pintails and mallards. Z. marina was a 


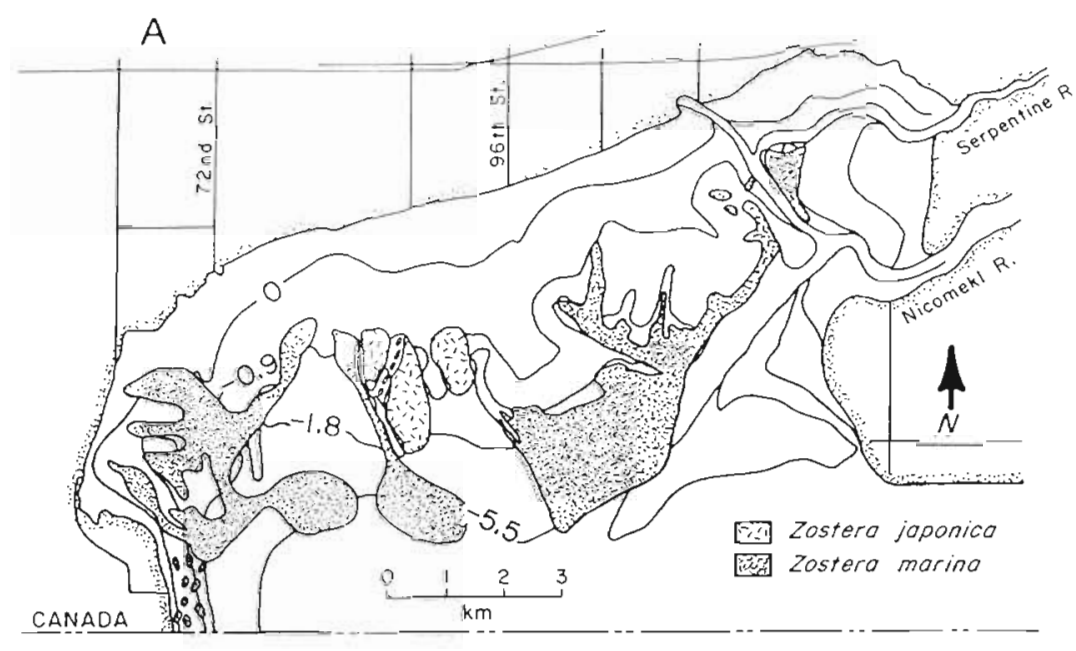

Fig. 3. Zostera spp. Estimated eelgrass distribution in Boundary Bay, British Columbia, (A) in July 1970 (Environment Canada unpubl. data) and (B) in October 1991. Transects for eelgrass sampling extended from the edge of the saltmarsh perpendicular to shoreline at 72 nd Street (Transect. 1, $2.2 \mathrm{~km}$ long) and 96th Street (Transect 2 , $2.6 \mathrm{~km}$ long)

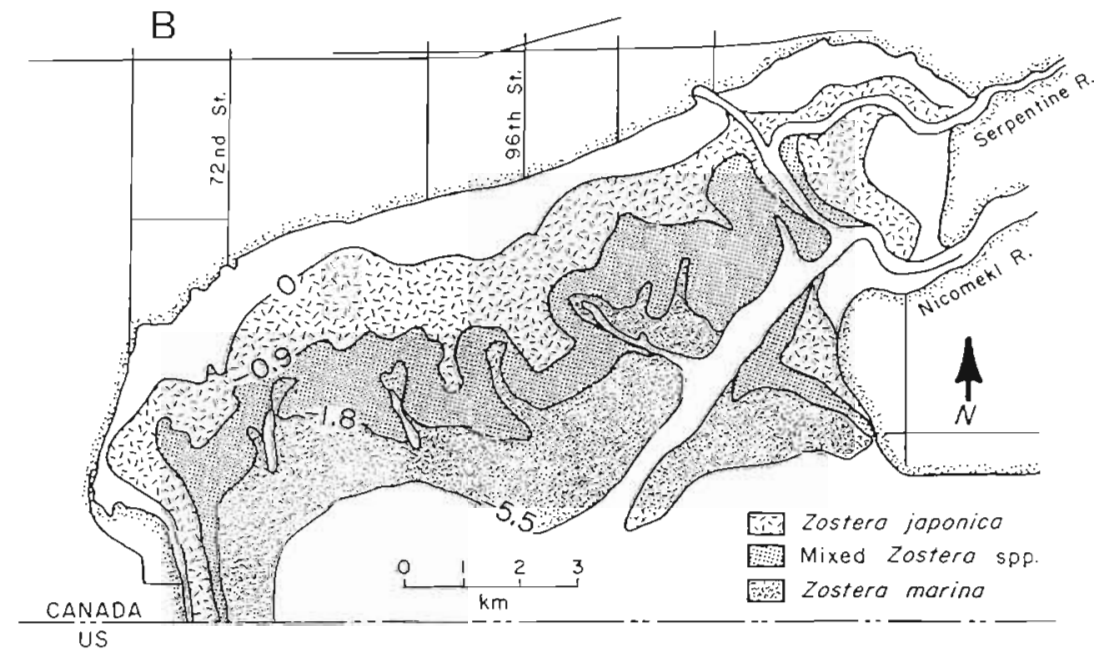

large portion of the brant diet $(41.2 \%)$, but had little importance ( 0.1 to $4.6 \%$ ) to the other species. Ulva sp.

Table 2. Area of different cover types in Boundary Bay, British Columbia, in October 1991 (see also Fig. 3B)

\begin{tabular}{|llc|}
\hline Flooding regime & \multicolumn{1}{c|}{ Cover type } & Area (ha) \\
\hline Infrequently flooded & Saltmarsh & 182 \\
High intertidal & Unvegetated sandflats & 598 \\
Mid intertidal & $\begin{array}{l}\text { Zostera japonica } \\
\text { Above Z. marina zone }\end{array}$ & 2161 \\
& Mixed with Z. marina & 1684 \\
& Total & 3845 \\
Low intertidal/ & Zostera marina & \\
subtidal & Mixed with Z. japonica a & 1684 \\
& Below Z. japonica zone & 1760 \\
& Total & 3444 \\
a Area of mixed Zostera species is included in the total for \\
each species & & \\
\hline
\end{tabular}

is usually found only as drift in Boundary Bay and comprised only 5.8 and $1.6 \%$ of the diet for wigeon and brant respectively. Ruppia maritima, which occurs throughout the bay but only in small patches, was seldom eaten.

\section{Energy content and biomass removed}

Mean energy content ( $\mathrm{kJ} \mathrm{g}^{-1}$ ) for Zostera marina was 16.817 ( $\mathrm{SE}=0.345, \mathrm{n}=23$ ) for leaves and 15.713 ( $\mathrm{SE}=$ $0.247, \mathrm{n}=14$ ) for rhizomes (no seeds were analyzed). For Z. japonica, values were $18.145(\mathrm{SE}=0.260, \mathrm{n}=19$ ) for leaves, 15.387 ( $\mathrm{SE}=0.640, \mathrm{n}=6$ ) for rhizomes and 18.999 ( $\mathrm{SE}=0.183, \mathrm{n}=2$ aggregate samples) for seeds. Leaves of $Z$. japonica had a higher energy content than leaves of $Z$. marina ( $t$-test; $p<0.005)$, but there was no difference between the rhizomes ( $t$-test; $p=0.61$ ).

Dabbling ducks and brant consumed an estimated $362.4 \mathrm{t}$ of Zostera japonica leaves and rhizomes in 


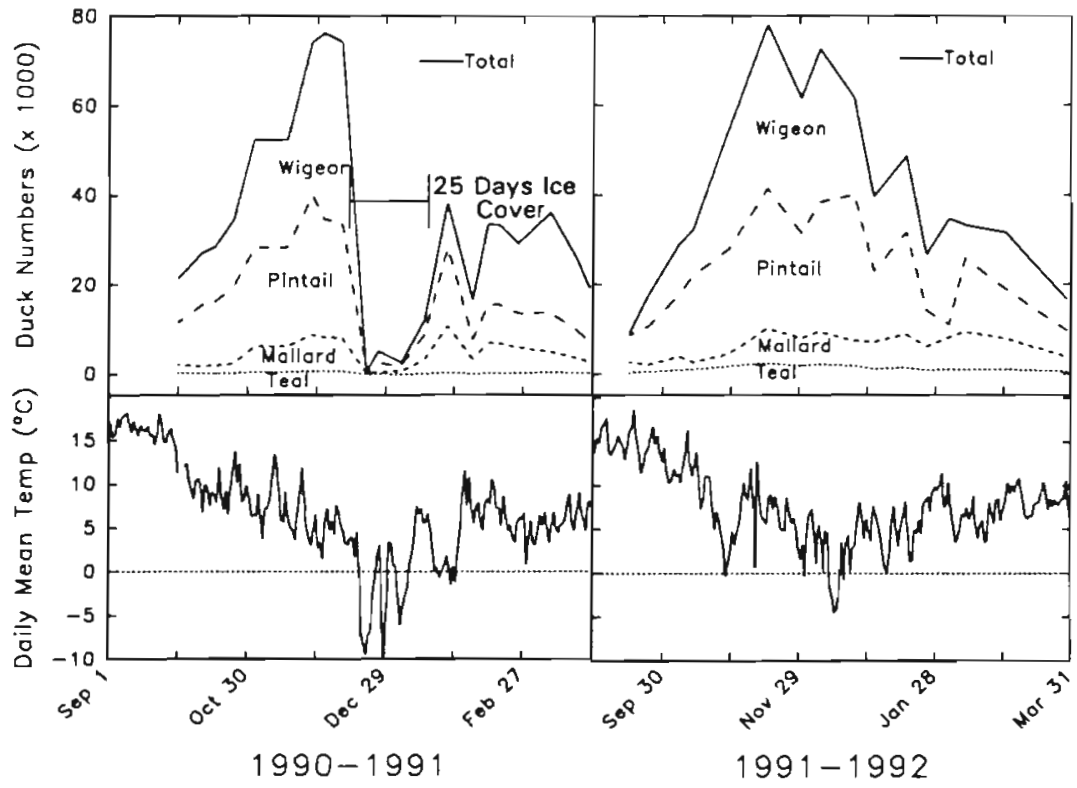

Fig. 4. Anas americana, A. acuta, A. platyrhynchos, A. crecca. Numbers of American wigeon, northern pintail, mallard and green-winged teal in Boundary Bay, British Columbia, in the winters of 1990-91 and 1991-92, and daily mean air temperatures from Vancouver International Airport (18 km northwest of Boundary Bay)

1991-92 (Table 5), which was $50.5 \%$ of the aboveground standing stock of $520 \mathrm{t}$ and $42.5 \%$ of the belowground biomass of $235 \mathrm{t}$ (see above).

\section{DISCUSSION}

In the last 25 yr, Zostera japonica has spread rapidly in Boundary Bay and the Puget Sound/Strait of Georgia region. Harrison \& Bigley (1982) documented its distribution from Coos Bay, Oregon, to Vancouver, British Columbia, with large beds occurring in Willapa Bay, Grays Harbor and Padilla Bay (Fig. 1). As of 1990, Z.

Table 3. Anas americana, A. acuta, A platyrhynchos. Medians and $15-85 \%$ quantiles (in parentheses) for percent time spent feeding at different tide heights (MWL) in Boundary Bay, British Columbia, 1 October to 7 December 1990. For medians without ranges there was no variation. Sample sizes refer to the number of $20 \mathrm{~s}$, focal-individual samples

\begin{tabular}{|cccc|}
\hline $\begin{array}{c}\text { Tide } \\
\text { height } \\
\text { (m) }\end{array}$ & $\begin{array}{c}\text { American } \\
\text { wigeon } \\
(\mathrm{n}=472)\end{array}$ & $\begin{array}{c}\text { Northern } \\
\text { pintail } \\
(\mathrm{n}=386)\end{array}$ & Mallard \\
$(\mathrm{n}=295)$ \\
\hline-1.1 to -0.6 & 100 & 100 & $100(0-100)$ \\
-0.6 to -0.3 & 100 & 100 & $75(0-100)$ \\
-0.3 to 0.0 & $25(0-100)$ & $1.00(65-100)$ & $80(0-100)$ \\
0.0 to 0.3 & $0(0-100)$ & $0(0-100)$ & $0(0-100)$ \\
0.3 to 0.6 & $0(0-100)$ & $0(0-30)$ & 0 \\
0.6 to 2.1 & 0 & 0 & 0 \\
\hline
\end{tabular}

japonica was not found in southern Puget Sound (Thom \& Hallum 1990) or in many isolated bays in the Strait of Georgia, but may eventually colonize all suitable habitat in the Pacific Northwest. In Boundary Bay, growth of $Z$. japonica in the middle to upper intertidal zone has added $2161 \mathrm{ha}$ of seagrass habitat, millions of bird use days, and hundreds of metric tonnes of organic matter. Sediment organic matter content of only $1.3 \%$ (authors unpubl. data) indicates that this large biomass of eelgrass detritus does not decompose in situ (cf. Hemminga \& Niewenhuize 1991), but rather decomposes in large heaps windrowed along shorelines (Koop \& Lucas 1983) or else is exported to deeper water.

Based on their energy requirements, waterfowl removed about $50 \%$ of the above-ground stock of Zostera japonica from September to March. This value is within the range reported for avian grazers in other seagrass systems by Ranwell \& Downing (1959; 30 to $75 \%)$, Kiorboe $(1980 ; 34$ to $67 \%)$, Jacobs et al. (1981; $51 \%$ ) and Mitchell (1991; $74 \%)$, and somewhat higher than that obtained by McRoy $(1966 ; 17 \%)$, Stieglitz $(1966 ; 32 \%)$, Anderson \& Low $(1976 ; 40 \%)$, Cornelius $(1977 ; 21 \%)$, Nienhuis \& Van Ierland $(1978 ; 1.5 \%$ of NPP May to August), Wilkins $(1982 ; 25 \%)$ and Ward (1983; 31\%). In addition to grazing impacts, mallards and pintails often accessed rhizomes by digging and enlarging pits in the sediment, similarly to waterfowl digging for Scirpus robustus rhizomes in North Carolina (Smith 1983) and for Z. noltii shoots and rhizomes in the Netherlands (Jacobs et al. 1981). Smith (1980) concluded that 18 to $31 \%$ of intertidal sediments in nearby Skagit Bay (Fig, 1) could be recovering from this type of waterfowl disturbance at a given time

Effects of Zostera japonica on other fauna have been addressed in only a few studies. Posey (1988) documented an overall increase in macroinvertebrate diversity and abundance with spread of $Z$. japonica. However, the tubeworm Praxillella gracilis and the ghost shrimp Neotrypaea californiensis, which burrow mostly in unvegetated sandflats, apparently avoid areas colonized by $Z$. japonica with its obstructing root system and perhaps greater predator densities (Harrison 1987). In nearby Padilla Bay (Fig 1), where some Z. japonica persists through winter owing to less exposure to storm waves, Thom et al. (1991) found that numbers of grazing isopods (mostly Idotea resecata) and gastropods (Lacuna variegata) per $\mathrm{m}^{2}$ of quadrat 
Table 4. Anas americana, A. acuta, A. platyrhynchos, Branta bernicla. Esophagus contents (\% dry mass) of birds collected in Boundary Bay, British Columbia, October to March 1990-92

\begin{tabular}{|c|c|c|c|c|c|}
\hline Food & $\begin{array}{l}\text { American } \\
\text { wigeon } \\
(n=45)\end{array}$ & $\begin{array}{l}\text { Northern } \\
\text { pintail } \\
(\mathrm{n}=54)\end{array}$ & $\begin{array}{l}\text { Mallard } \\
(n=20)\end{array}$ & $\begin{array}{l}\text { Green-winged } \\
\quad \text { teal } \\
(n=14)\end{array}$ & $\begin{array}{l}\text { Brant } \\
(n=62)\end{array}$ \\
\hline \multicolumn{6}{|l|}{ Zostera japonica } \\
\hline Seeds & - & 15.8 & 13.4 & 0.8 & - \\
\hline Leaves & 84.0 & 8.2 & 19.9 & 0.9 & 57.2 \\
\hline Rhizomes & 0.8 & 24.3 & 39.0 & - & - \\
\hline \multicolumn{6}{|l|}{ Zostera marina } \\
\hline Seeds & - & 0.6 & $\operatorname{Trace}^{\mathrm{b}}$ & 0.1 & - \\
\hline Leaves & 2.7 & 3.0 & 4.6 & - & 41.2 \\
\hline Rhizomes & - & Trace & - & - & Trace \\
\hline Ulva spp. & 5.8 & - & - & - & 1.6 \\
\hline Ruppia maritima & 1.0 & 0.2 & Trace & Trace & - \\
\hline Other $^{a}$ & 5.7 & 47.9 & 23.0 & 98.2 & - \\
\hline \multicolumn{6}{|c|}{$\begin{array}{l}\text { ¿Includes gastropods, amphipods, isopods, decapods, bivalves, oligochaetes, } \\
\text { insects, and seeds of Salicomia, Distichlis, Chenopodium, and Suaeda } \\
\text { (Baldwin \& Lovvorn 1992) } \\
{ }^{\circ} \text { Trace represented }<0.1 \% \text { dry mass }\end{array}$} \\
\hline
\end{tabular}

of both fish and waterbirds in this region (Vermeer \& Levings 1977 . MacDonald 1984, Simenstad et al. 1988, Thom et al. 1991, authors' unpubl. data).

The dominant paradigm for most seagrass ecosystems is that detrital pathways, as opposed to grazing, are the main routes to animal production (Kikuchi 1980, Simenstad 1983, Phillips 1984). This is thought to be especially true in temperate areas where there are few large herbivores as compared to the tropics (Ogden \& Lobel 1978, McRoy \& Helfferich 1980. McRoy \& Lloyd 1981, Zieman 1982). In tropical areas, large herb:vores include manatees, fish, turtles and birds, whereas birds are the only large herbivores in temperate seagrass systems. However, the role of birds should not be minimized. Phillips (1984) listed 19 species of birds in the Pacific Northwest of

Table 5. Anas americana, A. acuta, A. platyrhynchos, Branta bernicla. Use days and Zostera japonica consumption by 4 species of waterfowl in Boundary Bay, British Columbia, September to March 1990-91 and 1991-92

\begin{tabular}{|c|c|c|c|c|}
\hline \multirow[t]{2}{*}{ Species } & \multirow[t]{2}{*}{ Use days } & \multicolumn{3}{|c|}{ Z. japonica consumed (t) } \\
\hline & & Leaves & Rhizomes & Seeds \\
\hline \multicolumn{5}{|l|}{$1990-91$} \\
\hline Wigeon & 3252653 & 159.4 & 1.5 & - \\
\hline Pintail & 2510817 & 16.3 & 46.7 & 23.4 \\
\hline Mallard & 850829 & 13.9 & 26.3 & 6.9 \\
\hline Brant $^{d}$ & 10000 & 0.6 & - & - \\
\hline Total & 6624295 & 190.2 & 74.5 & 30.3 \\
\hline \multicolumn{5}{|l|}{$1991-92$} \\
\hline Wigeon & 3541339 & 221.9 & 2.0 & - \\
\hline Pintail & 3496011 & 22.7 & 65.1 & 32.5 \\
\hline Mallard & 1061046 & 17.3 & 32.8 & 8.7 \\
\hline Brant $^{a}$ & 10000 & 0.6 & - & - \\
\hline Total & 8198396 & 262.5 & 99.9 & 41.2 \\
\hline
\end{tabular}

samples were higher in $Z$. japonica than in Z. marina throughout their study period of October to July. The grazing amphipod Caprella laeviuscula was more numerous in $Z$. japonica in May to July. Numerical densities of decapods, gammarid amphipods, cumaceans and a variety of other invertebrates are also higher in $Z$. japonica than on unvegetated tidal flats (Dinnel et al. 1986, Simenstad et al. 1988, authors' unpubl. data). These invertebrates are important foods
North America which consume some portion of eelgrass, and underestimated the role of the numerous mallard and pintail by presuming they eat only seeds. Our results and others cited above (e.g. Ranwell \& Downing 1959, Kiorboe 1980, Jacobs et al. 1981), suggest that the trophic role of avian herbivores in temperate seagrass food webs may often be underemphasized.

Although Zostera japonica was introduced inadvertently, it may be an unusual example of an exotic species being generally beneficial to major components of an ecosystem. $Z$. japonica is now a principal food of migrating and wintering waterfowl in the Fraser Delta and other important sites such as Padilla Bay (Fig. 1). Z. japonica is also adding many metric tonnes of organic matter to the detrital system (Simenstad 1983), and birds grazing $Z$. japonica might bypass the slow decomposition process by excreting several tonnes of fecal nitrogen (cf. Thayer et al. 1982). For example, based on the estimated fecal output of European wigeon Anas penelsope of $65.2 \mathrm{~g}$ dry mass bird ${ }^{-1} \mathrm{~d}^{-1}$ (Mayhew 1988), American wigeon alone excrete $221 \mathrm{t}$ of feces into Boundary Bay in 7 mo. Greater consumption of the exotic $Z$. japonica than of native $Z$. marina by ducks and brant (Table 4) might result primarily from $Z$. japonica's longer accessibility during the daily tidal cycle (authors' unpubl. data). However, this diet pattern might also be influenced by the higher energy content of $Z$. japonica's leaves and easier handling of its smaller vegetative parts (Summers \& Atkins 1991). 
Acknowledgements. We appreciate logistical support and funding from the Canadian Wildlife Service (especially R. Butler, S. Freeman, G. Grigg, G. Dick, C. Copeland and S. Wetmore), the British Columbia Waterfowl Society, the Institute for Wetland and Waterfowl Research of Ducks Unlimited, and the U.S. Department of Energy

\section{LITERATURE CITED}

Altmann, J. (1974). Observational study of behaviour: sampling methods. Behaviour 49: 227-265

Anderson, M. G., Low, J. P. (1976). Use of sago pondweed by waterfowl on the Delta Marsh, Manitoba. J. Wildl. Mgmt 40: $233-242$

Baldwin, J. R., Lovvorn, J. R. (1992). Populations, diet, food availability and food requirements of dabbling ducks in Boundary Bay. In: Butler, R. W. (ed.) Abundance, distribution and conservation of birds in the vicinity of Boundary Bay, British Columbia. Can. Wildl. Serv. Tech. Rep. Ser. 155: 42-69

Bayley, S., Stotts, V D., Springer, P. F., Steenis, J. (1978). Changes in submerged aquatic macrophyte populations at the head of Chesapeake Bay, 1958-1975. Estuaries 1: $73-84$

Buchsbaum, R., Wilson, J., Valiela, I. (1986). Digestibility of plant constituents by Canada geese and Atlantic brant Ecology $67: 386-393$

Callaway, J. C., Josselyn, M. N. (1992). The introduction and spread of smooth cordgrass (Spartina alterniflora) in south San Francisco Bay. Estuaries 15: 218-226

Campbell, J. W. (1946). The food of the wigeon and brent goose. Br. Birds 39: 194-200

Charman, K. (1977). The grazing of Zostera by wildfowl in Britain. Aquaculture 12: 229-233

Charman, K. (1979). Feeding ecology and energetics of the dark-bellied brent goose (Branta bernicla bernicla) in Essex and Kent. In: Jeffries, R. L., Davy, A. J. (eds.) Ecological processes in coastal environments. Blackwell. Oxford, p. 451-465

Cornelius, S. E. (1977). Food and resource utilization by wintering redheads on lower Laguna Madre. J. Wildl. Mgmt 41. 374-385

Cottam, C., Lynch, J. J., Nelson, A. L. (1944). Food habits and management of American sea brant. J. Wildl. Mgmt 8: $36-56$

Den Hartog, C. (1970). The sea-grasses of the world. NorthHolland Publ. Co., Amsterdam

Dinnel, P. A., McMillan, R. O., Armstrong, D. A., Wamwright, T C. Whiley, A. J., Burge, R., Bumgarner, R. (1986). Padilla Bay Dungeness crab, Cancer magister, habitat study. Padilla Bay National Estuarine Res. Reserve Reprint Ser. 3, Mount Vernon, WA

Drent, R., Ebbinge, B., Weijand, B. (1978/79). Balancing the energy budgets of arctic-breeding geese throughout the annual cycle: a progress report. Verh. orn. Ges. Bayern 23: $239-264$

Forrester, W. D. (1983). Canadian tidal manual. Dept. Fish. Oceans, Can. Hydrogr. Serv., Ottawa

Grandy, J. W. (1972). Winter ecology of maritime black ducks (Anas rubripes) in Massachusetts: with special reference to Nauset Marsh, Orleans and Eastham. Ph.D. thesis, Univ. of Massachusetts, Amherst

Harrison, P. G. (1979). Reproductive strategies in intertidal populations of two co-occurring seagrasses (Zostera spp.). Can. J. Bot. 57: 2635-2638

Harrison, P. G. (1982a). Spatial and temporal patterns in abundance of two intertidal seagrasses, Zostera americana Den Hartog and Zostera marina L. Aquat. Bot. 12: $305-320$

Harrison, P. G. (1982b). Comparative growth of Zostera japonica Aschers. \& Graebn. and $Z$. marina L. under simulated intertidal and subtidal conditions. Aquat. Bot. 14 373-379

Harrison, P. G. (1987). Natural expansion and experimental manipulation of seagrass (Zostera spp.) abundance and the response of infaunal invertebrates. Estuar. coast. Shelf Sci. 24: 799-812

Harrison, P. G., Bigley, R. E. (1982). The recent introduction of the seagrass Zostera japonica Aschers. and Graebn. to the Pacific Coast of North America. Can. J. Fish. Aquat. Sci. 39: $1642-1648$

Hebert, P. D. N., Wilson, C. C., Murdoch, M. H., Lazar, R. (1991). Demography and ecological impacts of the invading mollusc Dreissena polymorpha. Can. J. Zool. 69: 405-409

Hemminga, M. A., Nieuwenhuize, J. (1991). Transport, deposition and in situ decay of seagrasses in a tropical mudflat area (Bane d'Arguin, Mauritania). Neth. J. Sea Res. 27: $183-190$

Jacobs, R. P. W. M. (1982). Reproductive strategies of two seagrass species (Zostera marina and $Z$. noltii) along west European coasts. In: Symoens, J. J., Hooper, S. S., Compere, P. (eds.) Studies on aquatic vascular plants. R. Bot. Soc. Belgium, Brussels, p. 150-155

Jacobs, R. P. W. M., Den Hartog, C., Braster, B. F., Carriere, F. C. (1981). Grazing of the seagrass Zostera noltii by birds at Terschelling (Dutch Wadden Sea). Aquat. Bot. 10: $241-259$

Karasov, W. H. (1990). Digestion in birds: chemical and physiological determinants and ecological implications. Stud avian Biol. 13: $391-415$

Kellerhals, P., Murray, J. W. (1969). Tidal flats at Boundary Bay, Fraser River Delta, British Columbia. Bull. Can Petrol. Geol. 17: 67-91

Kikuchi, T. (1980). Faunal relationships in temperate seagrass beds. In: Phillips, R. C., McRoy, C. P. (eds.) Handbook of seagrass biology, and ecosystem perspective. Garland STPM Press, New York, p. 153-172

Kiorboe, T (1980). Distribution and production of submerged macrophytes in Tipper Grund (Ringkobing Fjord, Denmark), and the impact of waterfowl grazing. J. appl. Ecol. 17: $675-687$

Koop, K., Lucas, M. I. (1983). Carbon flow and nutrient regeneration from the decomposition of macrophyte debris in a sandy beach microcosm. In: McLachlan, A., Erasmus, T. (eds.) Sandy beaches as ecosystems. Dr W. Junk Publ., The Hague, p. 249-262

MacDonald, A. L. (1984). Seasonal use of nearshore intertidal habitats by juvenile Pacific salmon on the delta-front of the Fraser River estuary, British Columbia. Ph.D. thesis, Univ. of Victoria, British Columbia

Mayhew, P. W. (1988). The daily energy intake of European wigeon in winter. Ornis Scand. 19: 217-223

McRoy, C. P. (1966). The standing stock and ecology of eelgrass (Zostera marina L.) in Izembek Lagoon. Alaska. M.Sc. thesis, Univ. of Washington, Seattle

McRoy, C. P. (1970). Standing stocks and other features of eelgrass (Zostera manina) populations on the coast of Alaska. J. Fish. Res. Bd Can. 27 1811-1821

McRoy, C. P., Helfferich, C. (1980). Applied aspects of seagrasses. In: Phillips, R. C., McRoy, C. P. (eds.) Handbook of seagrass biology, an ecosystem perspective. Garland STPM Press, New York, p. 297-343 
McRoy, C. P., Lloyd, D. S. (1981). Comparative function and stability of macrophyte-based ecosystems. In: Longhurst, A. R. (ed.) Analysis of marine ecosystems. Academic Press, New York, p. 473-489

Mitchell, C. A. (1991). Ecology of wintering redheads (Aythya americana) on the lower Laguna Madre, Texas. Ph.D. thesis, Louisiana State Univ., Baton Rouge

Morton, J. M., Fowler, A. C., Kirkpatrick, R. L. (1989). Time and energy budgets of American black ducks in winter J. Wildl. Mgmt 53: 401-410

Mukai, H., Aioi, K., Ishida, Y. (1980). Distribution and biomass of eelgrass (Zostera marina L.) and other seagrasses in Odawa Bay, central Japan. Aquat. Bot. 8: 337-342

Nichols, F. H., Pamatmat, M. M. (1988). The ecology of the soft-bottom benthos of San Francisco Bay: a community profile. Biol. Rep. U.S. Fish Wildl. Serv. 85(7.23)

Nienhuis, P. H., Van lerland, E. T. (1978). Consumption of eelgrass, Zostera marina, by birds and invertebrates during the growing season in Lake Grevelingen (SW Netherlands). Neth. J. Sea Res. 12: 180-194

Nienhuis, P. H., Groenendijk, A. M. (1986). Consumption of eelgrass (Zostera marina) by birds and invertebrates: an annual budget. Mar. Ecol. Prog. Ser. 29: 29-35

Nomme, K. M. (1989). Interactive biology of two seagrasses, Zostera marina L. and Zostera japonica Aschers. \& Graebn. M.Sc. thesis, Univ. of British Columbia, Vancouver.

Ogden, J. C., Lobel, P. S. (1978). The role of herbivorous fishes and urchins in coral reef communities. Environ. Biol. Fish. 3: $49-63$

Ogilvie, M. A., Matthews, G. V. T (1969). Brent geese, mudflats and man. Wildfowl 20: 119-125

Phillips, R. C. (1984). The ecology of eelgrass meadows in the Pacific Northwest: a community profile. U.S. Fish Wildl. Serv. FWS/OBS-84/24

Posey, M. H. (1988). Community changes associated with the spread of an introduced seagrass, Zostera japonica. Ecology 69: 974-983

Ranwell, D. S., Downing, B. M. (1959). Brent goose (Branta bernicla L.) winter feeding pattern and Zostera resources at Scolt Head Island, Norfolk. Anim. Behav. 7: 42-56

Simenstad, C. A. (1.983). The ecology of estuarine channels of the Pacific Northwest Coast: a community profile. U.S. Fish and Wildl. Serv. FWS/OBS-83/05

Simenstad, C. A., Cordell, J. R., Wissmar, R. C., Fresh, K. L., Schroder, S. L., Carr, M., Sanborn, G., Burg, M. (1988). Assemblage structure, microhabitat distribution, and food web linkages of epibenthic crustaceans in Padilla Bay National Estuarine Research Reserve, Washington. Padilla Bay National Estuarine Res. Reserve Reprint Ser. No. 9, Mount Vernon, WA

Smith, J. E. (1980). Seasonality, spatial dispersion patterns and migration of benthic invertebrates in an intertidal marsh-sandflat system of Puget Sound, Washington, and their relation to waterfowl foraging and the feeding ecology of staghorn sculpin, Leptocottus armatus. Ph.D. thesis, Univ. of Washington, Seattle

This article was submitted to the editor
Smith, T J. (1983). Alteration of salt marsh plant community composition by grazing snow geese. Holarc. Ecol. 6: $204-210$

Stieglitz, W. O. (1966). Utilization of available foods by diving ducks on Apalachee Bay, Florida. Proc. SE Assoc. Game Fish Comm. 20:42-50

Summers, R. W., Atkins, C. (1991). Selection by brent geese Branta bernicla for different leaf lengths of Aster tripolium on saltmarsh. Wildfowl 42: 33-36

Swanson, G. A., Krapu, G. L., Bartonek, J. C., Serie, J. R., Johnson, D. H. (1974). Advantages in mathematically weighting waterfowl food habits data. J. Wildl. Mgmt 38: 302-307

Thayer, G. W., Bjorndal, K. A., Ogden, J. C., Williams, S. L., Zieman, J. C. (1984). Role of larger herbivores in seagrass communities. Estuaries 7: 351-376

Thayer, G. W., Engel. D. W., Bjorndal, K. A. (1982). Evidence for short-circuiting of the detritus cycle of seagrass beds by the green turtle, Chelonia mydas L. J. exp. mar. Biol. Ecol. 62: 173-183

Thom, R. M. (1990). Spatial and temporal patterns in plant. standing stock and primary production in a temperate seagrass system. Botanica mar. 33: 497-510

Thom, R. M., Hallum, L. (1990). Long-term changes in the areal extent of tidal marshes, eelgrass meadows and kelp forests of Puget Sound. Fish. Res. Inst., Univ. of Washington, Seattle, FRI-UW-9008

Thom, R. M., Miller, B., Kennedy, M. (1991). Temporal patterns of grazers and vegetation in a temperate seagrass system. Fish. Res. Inst, Univ. of Washington, Seattle, FRIUW-9122

Tubbs, C. R., Tubbs, J. M. (1983). The distribution of Zostera and its exploitation by wildfowl in the Solent, southern England. Aquat. Bot. 15: 223-239

Verhoeven, J. T A. (1980). The ecology of Ruppia-dominated communites in western Europe. III. Aspects of production, consumption and decomposition. Aquat. Bot. 8: 209-253

Vermeer, K., Levings, C. D. (1977). Populations, biomass and foodhabits of ducks on the Fraser Delta intertidal area, British Columbia. Wildfow $128: 49-60$

Waldichuk, M. (1957). Physical oceanography of the Strait of Georgia, British Columbia. J. Fish. Res. Bd Can. 14: $321-486$

Ward, D. H. (1983). The relationship of two seagrasses: Zostera marina and Ruppia maritima to the black brant, Branta bernicla nigricans, San lgnacio Lagoon, Baja California, Mexico. M.Sc. thesis, Univ. of Oregon, Eugene

Wilkins, E. W. (1982). Waterfowl utilization of a submerged vegetation (Zostera marina and Ruppia maritima) bed in the lower Chesapeake Bay. M.Sc. thesis, College of William and Mary, Williamsburg

Yocom, C. F., Keller, M. (1961). Correlation of food habits and abundance of waterfowl. Humboldt Bay, California. Calif. Fish Game 47: 41-53

Zieman, J. C. (1982). The ecology of the seagrasses of south Florida: A community profile. U.S. Fish and Wildl Serv. FWS/OBS-82/25

Manuscript first received: June 22, 1993

Revised version accepted: October 6, 1993 